\title{
ANALISIS KETIMPANGAN PENDAPATAN DI PROVINSI ACEH
}

\author{
Meliza $^{* a}$, Murtala ${ }^{* b}$ \\ *Fakultas EkonomidanBisnis UniversitasMalikussaleh \\ a Corresponding author: Zameli755@gmail.com
}

\begin{tabular}{ll}
\hline A R T I C L E I N F O R M A T I O N & A B S T R A C T \\
\hline Keywords: & Thisstudyaimsto anatyze the factorsthatinfluence income inequatity in \\
income inequality. & Aceh Province. This study uses secondary data obtained from the \\
& Central Bureau of Statistics of Aceh Province in 2010-2017. Data \\
analysis techniques used are the williamsonindex, entropytheil index, & and multiplelinear regression analysis. Thetestresults using the \\
Williamson index show that income inequality in Aceh Province is still \\
quite high at 0.41\%, and from the entropy theil index testing shows very \\
high-income inequality at 1.47\%, Economic growth (Growth) does not \\
affect income inequality (INEQ) The unemployment rate (Unemp) does \\
not affect income inequality (INEQ), the Gross enrollment rate (GER) \\
affects income inequality (INEQ), and Agglomeration (Aglo) does not \\
affect income inequality (INEQ).
\end{tabular}

\section{PENDAHULUAN}

Pelaksanaan pembangunan serta perkembangan ekonomiyang tinggi suatu wilayah yaitu sasaran utama bagi tiap wilayah. perkembangan perekonomi yang terjadi dalam suatu periode tidak terlepas dari perkembangan masing-masing sektor atau subsektor yang ikut andil dalam membentuk surplus perekonomian suatu daerah. Produk Domestik Regional Bruto (PDRB) sebagai tolak ukur atau indikator yang mempunyai peran penting dalam mengukur keberhasilan pembangunan yang dicapai dan juga bisa dijadikan suatu ukuran dalam menentukan arah pembangunan suatu wilayah di waktu yang kelak nanti.

Pertumbuhan ekonomi di Provinsi Aceh dari tahun 2010-2017 sebesar 16,28\%, wilayah dengan tingkat pertumbuhan ekonomi yang sangat rendah bahkan dapat dikatakan menurun adalah Kota Lhokseumawe dengan laju pertumbuhan $37,88 \%$ hal ini disebabkan sumbangan dari Produk Domestik Regional Bruto atas harga konstan di Kota Lhokseumawe mengalami penurunan yang sangat drastic yaitu sebesar Rp. 2.497.756.500.000,- sehingga menyebabkan penurunan yang sangat signifikan.
Sedangkan untuk Kabupaten Aceh Timur laju pertumbuhan ekonomi berjalan sangat lambat dengan tingkat pertumbuhan sebesar $2,57 \%$. Walaupun Kabupaten AcehUtara merupakan salah satu Kabupaten yang paling tinggi sumbangan dari PDRB namun masih juga mengalami penurunan dengan laju pertumban hanya sebesar $10,23 \%$.

Namun dari pada itu Kota Banda Aceh laju pertumbuhan ekonomi yang paling tinggi jika dibandingkan dengan wilayah lain di Provinsi Aceh yaitu sebesar 27,82\% hal ini dikarenakan Kota Banda Aceh merupakan ibu kota dari Provinsi Aceh sehingga pergerakan perekonomian di daerah itu bisa dikatakan daerah tersibuk di Provinsi Aceh.

Ketimpangan pendapatan dan tingkat pengangguran.

Pengangguran terbesar ada di Kabupaten Aceh Utara yang pada tahun 2010 sebesar 46.851 jiwa dan mengalami penurunan pada tahun 2017 menjadi 24.672 jiwa walaupun menurunnya $89.90 \%$ jika disamakan dengan kabupaten/kota lain yang ada di Provinsi Aceh, Kabupaten Aceh Utara masih menduduki peringkat pertama dengan jumlah pengangguran terbesar, selanjutnya disusul 
oleh Kabupaten Aceh Timur dengan jumlah pengangguran pada tahun 2010 mencapai 16.683 jiwa kemudian mengalami penurunan sebesar 15.771 jiwa.

Bila dikaji lebih dalam, Kota Sabang yang mengalami penurunan pengangguran terbesar bila dilihat dari persentasenya yaitu sebesar 209,59\% kemudian selanjutnya baru KotaLhokseumawe sebesar $176,39 \%$

Begitu juga pendidikan sangat mempengaruhi ketimpangan pada suatu daerah, pendidikan dapat membentuk sumber daya manusia sehingga dengan sumber daya manusia yang mumpuni, dapat mengolah sumberdayaalam semaksimal mungkin yang berefek kepada peningkatan Produk Domestik Regional Bruto (PDRB).

Beberapa kabupaten yang mengalami penurunan angka partisipasi kasar, yang terparah terjadi di Kabupaten Aceh Barat Daya sebesar $78.25 \%$ selanjutnya disusul oleh Kabupaten Pidie Jaya sebesar 6,62\% dan Kabupaten Aceh Singkil sebesar $1,46 \%$. Untuk wilayah yang mengalami peningkatan angka partisipasi kasar yaitu Kota Subulussalam dengan peninggkatan sebesar $52.53 \%$.

Sedangkan untuk indikator yang digunakan dalam penelitian ini menggunakan 5 variabel yang diambil dari tahun 2010-2017 pada Provinsi Aceh dapat dilihat pada tabel berikut:

\section{Tabel 1}

Ketimpangan Pendapatan, Pertumbuhan Ekonomi, Tingkat Pengangguran, Angka Partisipasi Kasar dan Aglomerasi Provinsi Aceh Tahun 2010-2017

\begin{tabular}{|l|l|l|l|l|l|}
\hline $\begin{array}{l}\text { Ketimpan } \\
\text { gan } \\
\text { TahunPendapat } \\
\text { an } \\
\text { Y) }\end{array}$ & $\begin{array}{l}\text { Pertumbu } \\
\text { an } \\
\text { Ekonomi } \\
\text { X1) }\end{array}$ & $\begin{array}{l}\text { Tingkat } \\
\text { Penganggu } \\
\text { Xn } \\
\text { X2) }\end{array}$ & $\begin{array}{l}\text { Angka } \\
\text { Partisip } \\
\text { asi } \\
\text { Kasar } \\
\text { X3) }\end{array}$ & $\begin{array}{l}\text { Aglomer } \\
\text { lsi } \\
\text { X4) }\end{array}$ \\
\hline 2010 & 0.47 & 41.06 & 8.37 & 94.67 & 0.98 \\
\hline 2011 & 0.46 & 6.57 & 7.43 & 94.04 & 1.16 \\
\hline 2012 & 0.44 & 5.85 & 9.10 & 94.26 & 1.28 \\
\hline 2013 & 0.42 & 5.92 & 10.30 & 93.40 & 0.74 \\
\hline 2014 & 0.40 & 5.41 & 9.02 & 96.35 & 1.26 \\
\hline 2015 & 0.36 & 0.93 & 9.93 & 98.19 & 0.84 \\
\hline 2016 & 0.37 & 6.36 & 7.57 & 99.29 & 0.74 \\
\hline 2017 & 0.36 & 6.69 & 6.57 & 98.86 & 0.98 \\
\hline
\end{tabular}

Sumber: BPS Aceh (2011 \& 2018)
Tujuan penelitian ini untuk menganalisis besar tingkat ketimpangan pendapatan diProvinsi Aceh, untuk menganalisis hubungan pertumbuhan ekonomi terhadap ketimpangan pendapatan di Provinsi Aceh, dan untuk menganalisis pengaruh tingkat pengangguran, pertisipasi kasar dan aglomerasi terhadap ketimpangan pendapatan di Provinsi Aceh.

Penelitian sebelumnya yang meneliti tentang variabel pertumbuhan ekonomi terhadap ketimpangan pendapatan juga telah diteliti oleh (Istiqamah, Syaparuddin \& Rahmadi, 2018), (Amri, 2017), (Yuliani, 2015). Kemudian penelitian yang memberi fokus pada pengangguran terhadap ketimpangan pendapatan juga telah diteliti oleh (Ibnu \& Leila, 2019), (Nadya, 2019), (Hindun, 2019). Penelitian yang meneliti tentang partisipasi kasar terhadap ketimpangan pendapatan juga telah di teliti oleh (Sukron, 2019), (Imani, 2013). Kemudian penelitian aglomerasi terhadap ketimpangan pendapatan telah di teliti juga oleh (Hendarmin, 2019), (Vera, Malik \& Arifin, 2018), (Oktavia, 2017). Namun demikian, penelitian dengan variabelpertumbuhan ekonomi, tingkat pengangguran, angka partisipasi kasar dan aglomerasi terhadap ketimpangan pendapatan masih sangat sedikit peneliti yang memberikan perhatian khusus terhadap penelitian ini.

Selanjutnya pembahasan di bahagian kedua dalam artikel iniadalah landasan teoritis, di bahagian ketiga dibahas tentang metode penelitian. Pada bahagian keempat membahas hasil dan pembahasan dan akhirnya ditutup dengan kesimpulan dan saran pada bahagian kelima.

\section{LANDASAN TEORITIS}

\section{Ketimpangan Ekonomi Regional}

Ketimpangan/disparitas antar daerah merupakan hal yang biasa terjadi didalam proses kegiatann ekonomi sebuah daerah..

Selanjutnya menurut Sukirno (2013) mengartikan pembangunan ekonomi sebagai sejaras dalam suatu usaha perkonomian dengan cara meningkatkan kegiatan ekonomi ,menyediakan infrastruktur yang bersangkutan dengan kemajuan ekonomi ,serta mengembangkan tingkat pendidikan yang tingga serta membuka 
peluang pekerjaan dan menciptakan teknologi yang canggih serta peningkatan pendapatan kemakmuran masyarakat semakin melonjak.

Penelitian terkini tentang ketimpangan pendapatan banyak dilakukan oleh peneliti sekarang, seperti penelitian yang dilakukan oleh (Maydar, 2017) yang menelitiketimpangan pendapatandi Provinsi Aceh. Variabel bebas yang digunakan yaitu pendapatan per kapita dan jumlah penduduk. Menggunakan data sekunder dan menggunakan metode Formula koefisien Williamson.

\section{Pertumbuhan Ekonomi}

Pertumbuhan ekonomi diartikan sebagai proses yang menyebabkan pendapatan perkapita penduduk suatu masyarakat meningkat. Dimana kenaikan pendapatan merupakan suatu cerminan dari timbulnya perbaikan dalam kesejahteraan ekonomi masyarakat, akan tetapi diikuti oleh pemberantasan kemiskinan,penanggulangan ketimpangan pendapatan (Amalia, 2010).

Penelitian yang dilakukan oleh (Vera, 2018) dimana pertumbuhan ekonomi berpengaruh negatif terhadap ketimpangan wilayah, menggunakan data sekunder dan alat analisis regresi data panel.

Penelitian yang dilakukan oleh (Istiqamah, 2018) dimana pertumbuhan ekonomi berpengaruh positif terhadap ketimpangan pendapatan. Menggunakan data sekunder yang meliputi data deret waktu tahun 2010-2016 dan data deret lintang 34 Provinsi diIndonesia, alat analisis yang digunakan yaitu regresi data panel.

\section{Pengangguran}

Pengangguran juga diartikan sebagai keadaan yang menunjukkan suatu sumber daya yang tidak digunakan, dari beberapa definisi diatas dapat disimpulkan bahwa pengangguran adalah kelompok usia kerja yang termasuk angkatan kerja yang tidak memiliki pekerjaan atau sedang aktif mencari pekerjaan dan belum memperolehnya (Kurniawati, 2017).

Penelitian yang dilakukan oleh (Ibnu, 2019) dimana pengangguran berpengaruh terhadap ketimpangan pendapatan di Indonesia, menggunakan data sekunder dan alat analisis menggunakan Model Common Effect.
Penelitian yang dilakukan oleh (Hindun, 2019) dimana pengangguran tidak berpengaruh terhadap ketimpangan pendapatan di Indonesia. Penelitan ini menggunakan data sekunder dan alat analisis regresi data panel.

\section{AngkaPartisipasiKasar}

Angka partisipasi kasar ialah membandingkan keseluruhan siswa pada masa pendidikan tertentu sekelompok masyarakat umur sekolah dengan pedoman persentase.

Penelitian yang dilakukan oleh (Imani, 2013) dimana APK tidak berpengaruh terhadap ketimpangan pendapatan di Provinsi JawaTimur. Penelitan ini menggunakan alat analisis regresi linearberganda.

\section{Aglomerasi}

Aglomerasi yaitu pengelompokan special dari kegiatan ekonomi wilayah kota untuk menghemat tempat yang dekat.

Penelitian yang dilakukan oleh (Oktavia, 2017) dimana Aglomerasi berpengaruh terhadap ketimpangan pendapatan di Kabupaten Banyumas. Penelitan ini menggunakan alat analisis regresi linear berganda. Penelitian yang dilakukan oleh (Imani, 2013) dimana Aglomerasi berpengaruh terhadap disparitas wilayah di Provinsi Jawa Timur. Penelitan ini menggunakan alat analisis regresi linear berganda.

\section{Kerangka Pemikiran}

Untuk lebih jelas tentang kerangka pikir sehingga dapat memberikan jawaban sementara terhadap masalah yang akan diteliti, kerangka pemikiran operasional pada gambar 2.1.

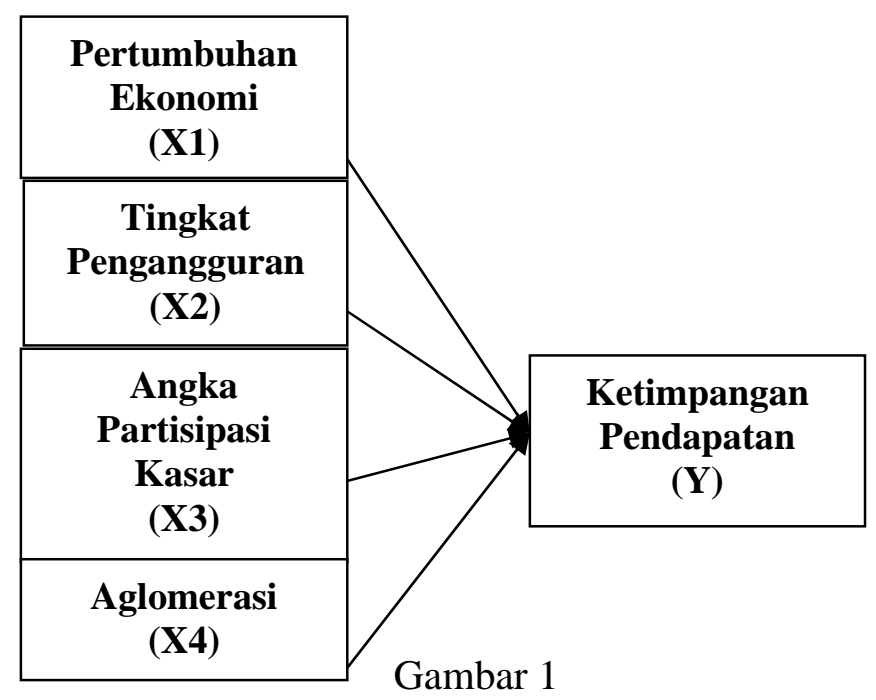

Kerangka Pemikiran 


\section{Hipotesis}

Bedasarkan teori, penelitian, dan kerangka berpikir yang telah dipaparkan diatas maka hipotesis dalam penelitian ini adalah :

1. Diduga pertumbuhan ekonomi berpengaruh positif dan signifikan terhadap ketimpangan pendapatan.

2. Diduga tingkat pengangguran berpengaruh positif terhadap ketimpangan pendapatan.

3. Diduga angka partisipasi kasar berpengaruh negatif terhadap ketimpangan pendapatan.

4. Diduga aglomerasi berpengaruh positif terhadap ketimpangan pendapatan.

\section{METODEPENELITIAN}

\section{Data dan Sumber Data}

Dikarenakan data dalam penelitian ini menggunakan data sekunder maka penelitian ini menggunakan objek dan subjek.Subjek penelitian ini adalah Badan Pusat Statistik Provinsi Aceh. Objek penelitian ini PDRB Atas Harga Konstan (Growth), tingkat pengangguran (Unemp), angka partisipasi kasar (APK) dan aglomerasi (Aglo).

\section{Operasional Variabel}

1. Variabel Dependen

1) Ketimpangan pendapatan (INEQ-Y) adalah perbedaan kemampuan suatu daerah dalam mendorong proses pembangunan.

2. Variabel Independen

1) Pertumbuhan (Growth- $X_{1}$ ) adalah nilai tambah bruto seluruh barang dan jasa yang dihasilkan di wilayah domestik suatu negara yang timbul akibat berbagai aktivitas ekonomi dalam suatu periode tertentu

2) Tingkat Pengangguran (Unemp- $X_{2}$ )adalah seorang yang sudah digolongkan dalam golongan pekerja (usia 15-64 tahun) yang sedang sedang mencari pekerjaan pada suatu tingkat upah tertentu, tetapi tidak memperoleh pekerjaan yang diinginkannya.

3) Angka Partisipasi Kasar $\left(\mathrm{APK}-\mathrm{X}_{3}\right)$ adalah persentase siswa dengan usia yang berkaitan dengan jenjang pendidikannya dari jumlah penduduk di usia yang sama

4) Aglomerasi(AGLO- $\left.X_{4}\right)$ adalah pemusatan industri di suatu kawasan tertentu dengan tujuan agar pengelolanya dapat optimal.

\section{Teknik Analisis Data \\ Indeks Williamson}

Indeks Williamson digunakan untuk menentukan besarnya kesenjangan pendapatan. indeks Williamson meneliti hubungan antara disparitas wilayah dengan klause pembangunan ekonomi ,menggunakan data ekonomi yang maju dan ekonomi yang berkembang,apakah ditemukan selama tahap awal pembangunan menjadi lebih besar pada pembangunan konsetntrasi di daerah tertentu.

Rumus:

$I 1=\frac{\sqrt{\sum(Y-Y)^{2} f / n}}{Y}$

Keterangan:

IW= Indeks Williamson

$\mathrm{Yi}=$ PDRB perkapita (dalam penelitian ini adalah kabupaten/kota)

$\mathrm{Y}=\mathrm{PDRB}$ perkapita (propinsi)

$\mathrm{fi}=$ Jumlah penduduk (dalam penelitian ini adalah kabupaten/kota)

$\mathrm{n}=$ Jumlah penduduk (propinsi)

Besarnya nilai ini bernilai positif dan berkisar antara angka $0-1$.Kesenjangan dikatakan tinggi apabila angka indeksnya 0,50 dan seterusnya.Apabila nilai indeksnya adalah 0 , maka dapat dikatakan bahwa didaerah tersebut tidak terjadi kesenjangan,atau dalam kata lain,daerah tersebut terjadi pemerataan sempurna.

\section{IndeksEntropiTheil}

Indeks ketimpangan Entropi Theil memungkinkan kita membuat perbandingan selama kurun waktu tertentu dan dapat menyediakan pengukuran ketimpangan secara rinci dalam subunit geografis yang lebih kecil.Berikut adalah rumus indeks Entropi Theil: $\mathrm{I}(\mathrm{y})=\Sigma(\mathrm{yj} / \mathrm{Y}) \mathrm{x} \log [(\mathrm{yj} / \mathrm{Y}) /(\mathrm{xj} / \mathrm{X})]$

Keterangan:

I(y):Indeks Entropi Theil

yj :PDRB perkapita kabupaten/kota j

$\mathrm{Y}$ :rata-rataPDRBperkapita provinsi

$\mathrm{xj}$ :jumlah pendudukkabupaten/kota j

$\mathrm{X}$ : jumlah penduduk Provinsi 


\section{Model RegresiLinearBerganda}

Penelitian ini akan menggunakan persamaan regresi linear berganda untuk mengetahui ada tidaknya pengaruh variabel bebas yaitu pertumbuhan ekonomi (Growth), Tingkat pengangguran (Unemp), Angka partisipasi kasar (APK)dan Aglomerasi (Aglo) terhadap variabel terikat yaitu ketimpangan pendapatan (INEQ). Model fungsi yang akan digunakan untuk mengetahui ketimpangan pendapatan diPropinsi Aceh tahun 2010-2017 yaitu :

INEQ = f (Growth, Unemp, APK, Aglo)

Dimana variabel yang digunakan adalah:

INEQ = ketimpangan pendapatan

Growth= pertumbuhan ekonomi

Unemp $=$ Tingkat pengangguran

APK = Angka partisipasi kasar

Aglo $=$ Aglomerasi

\section{INEQ $=\beta 0+\beta 1$ (Growth) $+\beta 2$ (Unemp) + $\beta 3(A P K)+\beta 4($ Aglo $)+E t$}

Fungsi di atas menjelaskan pengertian bahwa kesenjangan pendapatan 23 kabupaten/kota di Propinsi Aceh yang diukur dengan Indeks Williamson dipengaruhi oleh pertumbuhan ekonomi, tingkat pengangguran, angka partisipasi kasar dan aglomerasi serta variabel lain di luar model. Penelitian ini menggunakan asumsi bahwa variabel lain di luar variabel penelitian tidak berubah (ceteris paribus).

\section{Pengujian Asumsi Klasik}

\section{Uji Normalitas}

Uji Normalitas bertujuan untuk menguji apakah dalam model regresi, variabel dependen dan variabel independen kedua-duanya mempunyai distribusi normal atau tidak. Pengambilan kesimpulan dengan Jargue-Bera test atau $J-B$ test. Bila nilai J-B hitung $>$ nilai $\chi 2$ tabel, maka hipotesis yang menyatakan bahwa residual $\mu$ berdistribusi normal dapat ditolak. Bila nilai J-B hitung <nilai $\chi^{2}$ tabel,maka hipotesis yang menyatakan bahwa residual $\mu$ berdistribusi normal tidak dapat ditolak.

\section{Uji Multikolinieritas}

Uji multikolineritas adalah uji untuk melihat atau memastikan apakah dalam sebuah model tersebut adanya interkolerasi atau kolenieritas antar variabel bebas.model regresi yang baik pastinya tidak terjadi korelasi di antara varibel bebas

\section{Uji Heterokedastisitas}

Uji hetroskedastisitas yaitu untuk menguji apakah dalam model regresi terjadi ketidaksamaan varian dari residual satu pengamatan kepengamatan yang lain.Jika tetap,maka disebut homoskedatisitas dan jika berbeda disebut heteroskedastisitas. Pengujian dilakukan melalui uji Park. Jika $\mathrm{t}_{\text {statistik }}>\mathrm{t}_{\text {tabel }}$ maka ada heterokedastisitas, jika $t_{\text {statistik }}<t_{\text {tabel }}$ maka tidak ada.

\section{Uji Autokorelasi}

Uji autokorelasi yaitu untuk menguji apakah dalam model regresi linear ada korelasi antara kesalahan pengganggu pada periode waktu atau ruang dengan kesalahan pengganggu pada waktu atau ruang (sebelumnya).Pengujian menggunakan uji Durbin Watson untuk melihat gejala autokorelasi.

\section{Pengujian Statistik}

\section{Uji Koefisien Determinasi (Uji $\mathbf{R}^{\mathbf{2}}$ )}

Koefisiendeterminasi $\left(\mathrm{R}^{2}\right)$ merupakan regresi linier sering di artikan sebagai besar kemampuan variabel bebas dalam menjelaskan varians variabel terikatnya.adapun nilai-nilai R2 nya:

(a) Nilai $\mathrm{R}^{2}$ yang kecil atau mendekati nol, berarti kemampuan variable bebas dalam menjelaskan variasi variabel tidak bebas dan sangat terbatas.

(b)Nilai $\mathrm{R}^{2}$ mendekati satu,berarti kemampuan variabel-variabel bebas dalam menjelaskan hampir semua informasi yang digunakan untuk memprediksi variasi variabel tidak bebas. 


\section{Uji Signifikansi Parsial (Uji Statistik t)}

Uji statistik $t$ pada dasarnya menunjukan seberapa jauh pengaruh satu variabel independen secara individual dalam menerangkan variasi variabel dependen.Untuk mengkaji pengaruh variable independen terhadap dependen secara individu dapat dilihat hipotesis berikut :

1. $\mathrm{H}_{0}: \quad \beta 1=0$ tidak ada pengaruh variabel pertumbuhan ekonomi dengan ketimpangan pendapatan.

$\mathrm{H}_{0}: \beta 1>0$ ada pengaruh positif antara variabel pertumbuhan ekonomi dan ketimpangan pendapatan.

2. $\mathrm{H}_{0}: \beta 2=0$ tidak ada pengaruh antara variabel tingkat pengangguran dengan ketimpangan pendapatan.

$\mathrm{H}_{0}: \beta 2>0$ ada pengaruh positif antara tingkat pengangguran dan ketimpangan pendapatan.

3. $\mathrm{H}_{0}: \beta 3=0$ tidak ada pengaruh antara variabel angka partisipasi kasar dengan ketimpangan pendapatan.

$\mathrm{H}_{0}: \beta 3<0$ ada pengaruh negatif antara angka Partisipasi kasar dan ketimpangan pendapatan.

4. $\mathrm{H}_{0}: \beta 4=0$ tidaka da pengaruh antara variabel aglomerasi dengan ketimpangan pendapatan.

$\mathrm{H}_{0}: \beta 4>0$ ada pengaruh positif antara aglomerasi dengan ketimpangan pendapatan.

\section{Uji Signifikansi Simultan (Uji F)}

Uji F pada dasarnya dimaksudkan untuk membuktikan secara statistik bahwa seluruh variabel independen berpengaruh secara bersamasama terhadap variabel dependen yaitu kesenjangan pendapatan dengan hipotesis untuk menunjukkan apakah semua variabel bebas yang dimaksudkan dalam model mempunyai pengaruh secara bersama-sama terhadap variabel tak bebas. Hipotesis yang digunakanadalah sebagai berikut:
$\mathrm{H} 0: \beta 0=\beta 1=\beta 2=\beta 3=\ldots . .=0$

$\mathrm{H} 1: \beta 0 \nexists 1 \nexists 2 \nexists 33 \neq \ldots \ldots$

Kriteria pengujiannya apabila nilai $\mathrm{F}_{\text {hitung }}<$

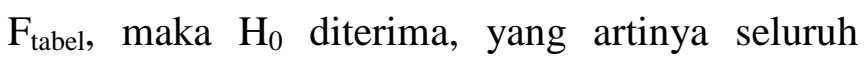
variabel independen yang digunakan tidak berpengaruh secara signifikan terhadap variabel dependen. Apabila Fhitung $>\mathrm{F}_{\text {tabel }}$, maka $\mathrm{H}_{0}$ ditolak, yang artinya seluruh variabel independen berpengaruh secara signifikan terhadap variabel dependen dengan taraf signifikan tertentu.

\section{HASILDANPEMBAHASAN}

\section{Uji Indeks Williamson dan Indeks Entropi Theil}

\section{Indeks Williamson Provinsi Aceh}

Dalampenelitian ini peneliti melakukan pengujian ketimpangan pada Provinsi Aceh yang melibatkan semua kabupaten/kota. Untuk lebih jelas ketimpangan di Provinsi Aceh dengan menggunakan pengukurusan Indeks Williamson dapat dilihat pada tabel 2 berikut.

Tabel 2

Indeks Williamson ProvinsiAceh Tahun 20102017

\begin{tabular}{|l|l|}
\hline Tahun & Indeks Williamson (persentase) \\
\hline 2010 & 0.47 \\
\hline 2011 & 0.46 \\
\hline 2012 & 0.44 \\
\hline 2013 & 0.42 \\
\hline 2014 & 0.40 \\
\hline 2015 & 0.36 \\
\hline 2016 & 0.37 \\
\hline 2017 & 0.36 \\
\hline Rata-rata & $\mathbf{0 . 4 1}$ \\
\hline
\end{tabular}

Sumber: Hasil Olahan Data Sekunder (2019)

Berdasarkan dari penjelasan dari tabel $2 \mathrm{di}$ atas maka dapat dijelaskan bahwa secara rata-rata keseluruhan pendapatan di Provinsi Aceh cukup tinggi yaitu dengan nilai indeks Williamson sebesar $0,41 \%$. Tahun yang mengalami ketimpangan pendapatan cukup tinggi terjadi pada tahun 2010 dengan nilai indeks sebesar 0,47\%, ketimpangan pendapatan yang tinggi ini 
disebabkan karena pendapatan pada tiaptiapdaerah yang sangat berbeda, ada daerah yang potensial dengan pengelolaan asset daerah yang sangat optimal sehingga menyumbang pendapatan terhadap PDRB yangtinggi sedangkan daerah lain dalam pengelolaan potensi daerah belum optimal sehingga pendapatan daerah masih sedikit diterima.

Sedangkan pada tahun 2015-2017 terjadi penurunan ketimpangan pendapatan sampai pada nilai indeks sebesar $0,36 \%$, penyebab terjadinya pemerataan pendapatan yang semakin baik karena pemerintah Provinsi Aceh mulai membuka lapangan usaha baru pada daerah-daerah yang memiliki potensi pertanian maupun perkebunan yang tinggi serta membuka kerja sama dengan pihak asing untuk melakukan penanaman modal di wilayah tersebut sehingga dapat meningkatkan pemerataan pendapatan daerah.

\section{Indeks EntropiTheilProvinsi Aceh}

Ketentuan dalam indeks Entropi Theil apabila mendekati 1 atau lebih maka terjadi ketimpangan yang semakin besar dan apabila mendekati 0 maka ketimpangan semakin mengecil atau semakin rata-rata. Berikut pengujian Indeks Entropi Theil Provinsi Aceh.

Tabel 3

Indeks Entropi Theil Provinsi Aceh Tahun 2010-2017

\begin{tabular}{|l|l|}
\hline Tahun & Indeks Entropi Theil (persentase) \\
\hline 2010 & 1.47 \\
\hline 2011 & 1.46 \\
\hline 2012 & 1.46 \\
\hline 2013 & 1.46 \\
\hline 2014 & 1.46 \\
\hline 2015 & 1.47 \\
\hline 2016 & 1.47 \\
\hline 2017 & 1.47 \\
\hline
\end{tabular}

Sumber: Hasil Olahan Data Sekunder (2019)

Dari hasil penjelasan pada tabel 3 indeks

Entropi Theil Provinsi Aceh mengalami ketimpangan yang sangat tinggi, dalam penelitian ini tingkat ketimpangan ekonomi Provinsi Aceh dari tahun 2010-2017mengalami ketimpangan sebesar 1,47\%. Sehingga setiap daerah di Provinsi Aceh mengalami ketimpangan pendapatan.

\section{Tabel 4}

Indeks Entropi Theil Kabupaten/Kota di Provinsi Aceh Tahun 2010-2017

\begin{tabular}{|c|c|c|c|c|c|c|c|c|c|}
\hline No & $\begin{array}{l}\text { Kabupate } \\
\text { n/Kota }\end{array}$ & $\begin{array}{l}20 \\
10\end{array}$ & $\begin{array}{l}20 \\
11\end{array}$ & $\begin{array}{l}20 \\
12\end{array}$ & $\begin{array}{l}20 \\
13\end{array}$ & $\begin{array}{l}20 \\
14\end{array}$ & $\begin{array}{l}20 \\
15\end{array}$ & $\begin{array}{l}20 \\
16\end{array}$ & $\begin{array}{l}20 \\
17\end{array}$ \\
\hline 1 & $\begin{array}{l}\text { Kab. } \\
\text { Simeulue }\end{array}$ & $\begin{array}{l}0.9 \\
5\end{array}$ & $\begin{array}{l}0.9 \\
7\end{array}$ & $\begin{array}{l}1.0 \\
4\end{array}$ & $\begin{array}{l}1.1 \\
0\end{array}$ & $\begin{array}{l}1.0 \\
9\end{array}$ & $\begin{array}{l}1.1 \\
6\end{array}$ & $\begin{array}{l}1.1 \\
9\end{array}$ & $\begin{array}{l}1.1 \\
9\end{array}$ \\
\hline 2 & $\begin{array}{l}\text { Kab. Aceh } \\
\text { Singkil }\end{array}$ & $\begin{array}{l}0.7 \\
5\end{array}$ & $\begin{array}{l}0.7 \\
8\end{array}$ & $\begin{array}{l}0.8 \\
0\end{array}$ & $\begin{array}{l}0.8 \\
1\end{array}$ & $\begin{array}{l}0.8 \\
4\end{array}$ & $\begin{array}{l}0.8 \\
9\end{array}$ & $\begin{array}{l}0.9 \\
2\end{array}$ & $\begin{array}{l}0.9 \\
2\end{array}$ \\
\hline 3 & $\begin{array}{l}\text { Kab. Aceh } \\
\text { Selatan }\end{array}$ & $\begin{array}{l}0.7 \\
5\end{array}$ & $\begin{array}{l}0.7 \\
8\end{array}$ & $\begin{array}{l}0.8 \\
2\end{array}$ & $\begin{array}{l}0.8 \\
6\end{array}$ & $\begin{array}{l}0.8 \\
4\end{array}$ & $\begin{array}{l}0.8 \\
9\end{array}$ & $\begin{array}{l}0.9 \\
1 \\
\end{array}$ & $\begin{array}{l}0.9 \\
1\end{array}$ \\
\hline 4 & $\begin{array}{l}\text { Kab. Aceh } \\
\text { Tenggara }\end{array}$ & $\begin{array}{l}0.7 \\
2 \\
\end{array}$ & $\begin{array}{l}0.7 \\
5\end{array}$ & $\begin{array}{l}0.7 \\
9\end{array}$ & $\begin{array}{l}0.8 \\
3 \\
\end{array}$ & $\begin{array}{l}0.8 \\
2 \\
\end{array}$ & $\begin{array}{l}0.8 \\
7\end{array}$ & $\begin{array}{l}0.8 \\
9\end{array}$ & $\begin{array}{l}0.9 \\
1 \\
\end{array}$ \\
\hline 5 & $\begin{array}{l}\text { Kab. Aceh } \\
\text { Timur }\end{array}$ & $\begin{array}{l}1.0 \\
0\end{array}$ & $\begin{array}{l}0.9 \\
9\end{array}$ & $\begin{array}{l}0.9 \\
6\end{array}$ & $\begin{array}{l}0.9 \\
1\end{array}$ & $\begin{array}{l}0.9 \\
0\end{array}$ & $\begin{array}{l}0.7 \\
9\end{array}$ & $\begin{array}{l}0.7 \\
6\end{array}$ & $\begin{array}{l}0.7 \\
5\end{array}$ \\
\hline 6 & $\begin{array}{l}\text { Kab. Aceh } \\
\text { Tengah }\end{array}$ & $\begin{array}{l}1.5 \\
0\end{array}$ & $\begin{array}{l}1.5 \\
3\end{array}$ & $\begin{array}{l}1.5 \\
8\end{array}$ & $\begin{array}{l}1.6 \\
4\end{array}$ & $\begin{array}{l}1.6 \\
4\end{array}$ & $\begin{array}{l}1.7 \\
3\end{array}$ & $\begin{array}{l}1.7 \\
4\end{array}$ & $\begin{array}{l}1.7 \\
2\end{array}$ \\
\hline 7 & $\begin{array}{l}\text { Kab. Aceh } \\
\text { Barat }\end{array}$ & $\begin{array}{l}1.7 \\
8\end{array}$ & $\begin{array}{l}1.7 \\
3\end{array}$ & $\begin{array}{l}1.6 \\
2\end{array}$ & $\begin{array}{l}1.6 \\
1\end{array}$ & $\begin{array}{l}1.6 \\
7\end{array}$ & $\begin{array}{l}1.7 \\
5\end{array}$ & $\begin{array}{l}1.7 \\
3\end{array}$ & $\begin{array}{l}1.8 \\
3\end{array}$ \\
\hline 8 & $\begin{array}{l}\text { Kab. Aceh } \\
\text { Besar }\end{array}$ & $\begin{array}{l}1.0 \\
1 \\
\end{array}$ & $\begin{array}{l}1.0 \\
1\end{array}$ & $\begin{array}{l}1.0 \\
1\end{array}$ & $\begin{array}{l}1.0 \\
2\end{array}$ & $\begin{array}{l}1.1 \\
0\end{array}$ & $\begin{array}{l}1.1 \\
5\end{array}$ & $\begin{array}{l}1.1 \\
4\end{array}$ & $\begin{array}{l}1.1 \\
2\end{array}$ \\
\hline 9 & Kab. Pidie & $\begin{array}{l}0.5 \\
8 \\
\end{array}$ & $\begin{array}{l}0.5 \\
9\end{array}$ & $\begin{array}{l}0.6 \\
1 \\
\end{array}$ & $\begin{array}{l}0.6 \\
4 \\
\end{array}$ & $\begin{array}{l}0.6 \\
5 \\
\end{array}$ & $\begin{array}{l}0.6 \\
9\end{array}$ & $\begin{array}{l}0.7 \\
1 \\
\end{array}$ & $\begin{array}{l}0.7 \\
2 \\
\end{array}$ \\
\hline 10 & $\begin{array}{l}\text { Kab. } \\
\text { Bireun }\end{array}$ & $\begin{array}{l}0.8 \\
4 \\
\end{array}$ & $\begin{array}{l}0.8 \\
5\end{array}$ & $\begin{array}{l}0.8 \\
7\end{array}$ & $\begin{array}{l}0.8 \\
9\end{array}$ & $\begin{array}{l}0.8 \\
9\end{array}$ & $\begin{array}{l}0.9 \\
2\end{array}$ & $\begin{array}{l}0.9 \\
2\end{array}$ & $\begin{array}{l}0.9 \\
0\end{array}$ \\
\hline 11 & $\begin{array}{l}\text { Kab. Aceh } \\
\text { Utara }\end{array}$ & $\begin{array}{l}1.6 \\
6\end{array}$ & $\begin{array}{l}1.7 \\
2\end{array}$ & $\begin{array}{l}1.7 \\
2\end{array}$ & $\begin{array}{l}1.6 \\
4\end{array}$ & $\begin{array}{l}1.4 \\
8\end{array}$ & $\begin{array}{l}1.0 \\
7\end{array}$ & $\begin{array}{l}1.0 \\
1\end{array}$ & $\begin{array}{l}0.9 \\
9\end{array}$ \\
\hline 12 & $\begin{array}{l}\text { Kab. Aceh } \\
\text { Barat Daya }\end{array}$ & $\begin{array}{l}1.2 \\
1\end{array}$ & $\begin{array}{l}1.2 \\
1\end{array}$ & $\begin{array}{l}1.2 \\
0\end{array}$ & $\begin{array}{l}1.1 \\
9\end{array}$ & $\begin{array}{l}1.1 \\
6\end{array}$ & $\begin{array}{l}1.2 \\
1\end{array}$ & $\begin{array}{l}1.2 \\
2\end{array}$ & $\begin{array}{l}1.2 \\
1\end{array}$ \\
\hline 13 & $\begin{array}{l}\text { Kab. Gayo } \\
\text { Lues }\end{array}$ & $\begin{array}{l}1.3 \\
5\end{array}$ & $\begin{array}{l}1.3 \\
9\end{array}$ & $\begin{array}{l}1.4 \\
5\end{array}$ & $\begin{array}{l}1.4 \\
8\end{array}$ & $\begin{array}{l}1.5 \\
2\end{array}$ & $\begin{array}{l}1.5 \\
9\end{array}$ & $\begin{array}{l}1.6 \\
2\end{array}$ & $\begin{array}{l}1.6 \\
5\end{array}$ \\
\hline 14 & $\begin{array}{l}\text { Kab. Aceh } \\
\text { Tamiang }\end{array}$ & $\begin{array}{l}0.9 \\
4 \\
\end{array}$ & $\begin{array}{l}0.9 \\
2\end{array}$ & $\begin{array}{l}0.9 \\
3\end{array}$ & $\begin{array}{l}0.9 \\
8\end{array}$ & $\begin{array}{l}0.9 \\
6\end{array}$ & $\begin{array}{l}0.9 \\
4\end{array}$ & $\begin{array}{l}0.9 \\
3\end{array}$ & $\begin{array}{l}0.9 \\
4\end{array}$ \\
\hline 15 & $\begin{array}{l}\text { Kab. } \\
\text { Nagan } \\
\text { Raya }\end{array}$ & $\begin{array}{l}2.5 \\
7\end{array}$ & $\begin{array}{l}2.5 \\
6\end{array}$ & $\begin{array}{l}2.4 \\
3\end{array}$ & $\begin{array}{l}2.3 \\
4\end{array}$ & $\begin{array}{l}2.3 \\
6\end{array}$ & $\begin{array}{l}2.4 \\
4\end{array}$ & $\begin{array}{l}2.4 \\
3\end{array}$ & $\begin{array}{l}2.4 \\
1\end{array}$ \\
\hline 16 & $\begin{array}{l}\text { Kab. Aceh } \\
\text { Jaya }\end{array}$ & $\begin{array}{l}1.4 \\
6\end{array}$ & $\begin{array}{l}1.4 \\
7\end{array}$ & $\begin{array}{l}1.4 \\
1\end{array}$ & $\begin{array}{l}1.3 \\
5\end{array}$ & $\begin{array}{l}1.4 \\
3\end{array}$ & $\begin{array}{l}1.5 \\
4\end{array}$ & $\begin{array}{l}1.5 \\
5\end{array}$ & $\begin{array}{l}1.5 \\
5\end{array}$ \\
\hline 17 & $\begin{array}{l}\text { Kab. Bener } \\
\text { Meriah }\end{array}$ & $\begin{array}{l}1.4 \\
0\end{array}$ & $\begin{array}{l}1.4 \\
3\end{array}$ & $\begin{array}{l}1.4 \\
5\end{array}$ & $\begin{array}{l}1.4 \\
7\end{array}$ & $\begin{array}{l}1.5 \\
2\end{array}$ & $\begin{array}{l}1.6 \\
0\end{array}$ & $\begin{array}{l}1.5 \\
9\end{array}$ & $\begin{array}{l}1.5 \\
5\end{array}$ \\
\hline 18 & $\begin{array}{l}\text { Kab. Pidie } \\
\text { Jaya }\end{array}$ & $\begin{array}{l}0.8 \\
1\end{array}$ & $\begin{array}{l}0.8 \\
2\end{array}$ & $\begin{array}{l}0.8 \\
5\end{array}$ & $\begin{array}{l}0.8 \\
7\end{array}$ & $\begin{array}{l}0.8 \\
7\end{array}$ & $\begin{array}{l}0.9 \\
3\end{array}$ & $\begin{array}{l}0.9 \\
3\end{array}$ & $\begin{array}{l}0.9 \\
4\end{array}$ \\
\hline 19 & $\begin{array}{l}\text { Kota Banda } \\
\text { Aceh }\end{array}$ & $\begin{array}{l}3.3 \\
8\end{array}$ & $\begin{array}{l}3.4 \\
0\end{array}$ & $\begin{array}{l}3.3 \\
5\end{array}$ & $\begin{array}{l}3.3 \\
1\end{array}$ & $\begin{array}{l}3.4 \\
9\end{array}$ & $\begin{array}{l}3.7 \\
6\end{array}$ & $\begin{array}{l}3.8 \\
7\end{array}$ & $\begin{array}{l}3.8 \\
1\end{array}$ \\
\hline 20 & $\begin{array}{l}\text { Kota } \\
\text { Sabang }\end{array}$ & $\begin{array}{l}2.5 \\
0\end{array}$ & $\begin{array}{l}2.5 \\
3\end{array}$ & $\begin{array}{l}2.5 \\
8\end{array}$ & $\begin{array}{l}2.6 \\
3\end{array}$ & $\begin{array}{l}2.7 \\
1\end{array}$ & $\begin{array}{l}2.8 \\
8\end{array}$ & $\begin{array}{l}2.9 \\
5\end{array}$ & $\begin{array}{l}3.0 \\
6\end{array}$ \\
\hline 21 & $\begin{array}{l}\text { Kota } \\
\text { Langsa }\end{array}$ & $\begin{array}{l}1.1 \\
3\end{array}$ & $\begin{array}{l}1.1 \\
4\end{array}$ & $\begin{array}{l}1.1 \\
8\end{array}$ & $\begin{array}{l}1.2 \\
1\end{array}$ & $\begin{array}{l}1.2 \\
3\end{array}$ & $\begin{array}{l}1.3 \\
2\end{array}$ & $\begin{array}{l}1.3 \\
6\end{array}$ & $\begin{array}{l}1.3 \\
7\end{array}$ \\
\hline 22 & $\begin{array}{l}\text { Kota } \\
\text { Lhokseuma } \\
\text { we }\end{array}$ & $\begin{array}{l}4.4 \\
7\end{array}$ & $\begin{array}{l}4.0 \\
9\end{array}$ & $\begin{array}{l}3.9 \\
6\end{array}$ & $\begin{array}{l}3.7 \\
9\end{array}$ & $\begin{array}{l}3.3 \\
8\end{array}$ & $\begin{array}{l}2.5 \\
2\end{array}$ & $\begin{array}{l}2.3 \\
5\end{array}$ & $\begin{array}{l}2.2 \\
6\end{array}$ \\
\hline 23 & $\begin{array}{l}\text { Kota } \\
\text { Subulussal } \\
\text { am }\end{array}$ & $\begin{array}{l}1.0 \\
0\end{array}$ & $\begin{array}{l}1.0 \\
1\end{array}$ & $\begin{array}{l}1.0 \\
2\end{array}$ & $\begin{array}{l}1.0 \\
2\end{array}$ & $\begin{array}{l}1.0 \\
6\end{array}$ & $\begin{array}{l}1.1 \\
1\end{array}$ & $\begin{array}{l}1.1 \\
3\end{array}$ & $\begin{array}{l}1.1 \\
5\end{array}$ \\
\hline
\end{tabular}

Sumber: Hasil Olahan Data Sekunder (2019)

Jika hasil tabel diatas 4 tingkat disparitas wilayahdi provinsi aceh relatif tinggi indeks Entropi Theil tidak lebih kecil dari 0,50\%. Wilayah dengan tingkat ketimpangan ekonomi dan industri terparah sendiri terjadi di Kota Lhokseumawe dengan indeks Entropi Theil pada tahun 2010 mencapai 4,47\%, walaupun Kota 
Lhokseumawe merupakan kota dengan PDRB paling tinggi dibandingkan dengan wilayah lain namun pendapatan masyarakatnya tidak merata, walaupun terjadi penurunan ketimpangan ekonomi pada tahun 2017 menjadi sebesar 2,26\% tetapi masih dalam ketimpangan yang tinggi, selanjunya Kota Banda Aceh juga mengalami ketimpangan ekonomi yang terparah walaupun Kota Banda Aceh merupakan ibukota Provinsi Aceh dengan tingkat ketimpangan sebesar 3\% sepanjang tahun, disusul Kota Sabang yang juga pengalami ketimpangan ekonomi sepanjang tahun penelitian sebesar $2 \%$.

\section{Uji Normalitas}

Uji Normalitasbertujuanuntuk menguji apakah dalam model regresi,variabel dependen dan variabel independen kedua-duanya mempunyai distribusi normal atau tidak. Ketentuan dalam penentuan normal tidaknya data sebagai berikut:

- Nilai J-B hitung > nilaix2 tabel, maka hipotesis yang menyatakan bahwa residual $\mu$ berdistribusi tidak normal.

- Nilai J-B hitung < nilai $\chi^{2}$ tabel, maka hipotesis yang menyatakan bahwa residual $\mu$ berdistribusi normal.

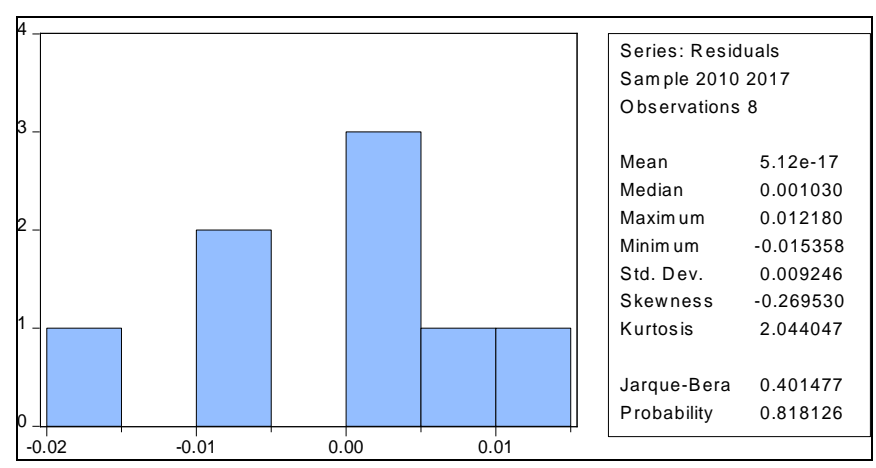

Sumber: Hasil Olahan Data Sekunder (2019)

\section{Gambar 2}

Uji Normalitas

Berdasarkandari Gambar 2 di atas maka dapat dilihat nilai Jarque-Bera sebesar 0,401477 dan jika dibandikan dengan nilai $\chi 2$ tabel (Chi square) pada sebesar15,51 didapatkan 0,401477 < 15,15 maka hipotesis yang menyatakan bahwa residual $\mu$ berdistribusi normal.

\section{Hasil Pengujian}

\section{Uji Asumsi Klasik}

\section{Uji Multikolinearitas}

Uji multikolinearitas menilai adakah korelasi atau interkorelasi antar variabel bebas dalam model regresi. Dengan ketentuan jika nilai VIF kurang dari 10 maka dinyatakan tidak terdapat masalah multikolinearitas. Berikut pengujian multikolinearitas yang dapat dilihap pada tabel 5 .

\section{Tabel 5}

Uji Multikolinearitas

\begin{tabular}{|l|l|l|l|}
\hline Variable & $\begin{array}{l}\text { Coefficient } \\
\text { Variance }\end{array}$ & \multicolumn{2}{|l|}{ Uncentered Centered } \\
VIF & VIF \\
\hline C & 0.115865 & 4647.079 & NA \\
\hline Growth & $2.17 \mathrm{E}-07$ & 2.079983 & 1.236573 \\
\hline Unemp & $2.46 \mathrm{E}-05$ & 73.39666 & 1.438857 \\
\hline APK & $9.65 \mathrm{E}-06$ & 3578.931 & 1.895643 \\
\hline Aglo & 0.000779 & 31.61426 & 1.358360 \\
\hline
\end{tabular}

Sumber: Hasil Olahan Data Sekunder (2019)

Berdasarkan dari hasil pengujian multikolinearitas maka di dapatkan bahwa nilai Centered VIF pada semua variable dependen nilainya kurang dari 10, maka dapat dinyatakan bahwa tidak terdapat masalah multikolinearitas dalam model prediksi.

\section{Uji Heterokedastisitas}

Ketentuan jika nilai Prob > 0,05 maka tidak ada heterokedastisitas, jika nilai Prob $<0,05$ maka ada heterokedastisitas. Berikut hasil pengujian heterokedastisitas pada tabel 6 .

\section{Tabel 6}

\section{Uji Heterokedastisitas}

Heteroskedasticity Test: Breusch-Pagan-Godfrey \begin{tabular}{|l|l|l|l|}
\hline F-statistic & 9.190435 & Prob. F(4,3) & 0.0495
\end{tabular}

\begin{tabular}{|l|l|}
\hline Obs*R- & Prob. Chi-
\end{tabular}

\begin{tabular}{|l|l|cr|r|} 
squared & 7.396405 & Square(4) & 0.1164 \\
\hline $\begin{array}{l}\text { Scaled } \\
\text { explained SS }\end{array}$ & 0.542967 & Prob. & Chi- & \\
& & & \\
Suare(4) & & 0.9692 \\
\hline
\end{tabular}

Sumber: Hasil Olahan Data Sekunder (2019)

Dari hasil pengujian heterokedastisitas pada tabel 4.10 maka dapat dilihat bahwa nilai pada Obs $^{\star}$ R-Squared yaitu sebesar 0,1164.Oleh karena nilai $p$ value $0,1164>0,05$ maka model regresi bersifat homoskedastisitas atau tidak ada masalah asumsi non heteroskedastisitas. 


\section{Uji Autokerelasi}

Uji auto korelasi bertujuan menguji apakah dalam model regresi linear ada korelasi antara kesalahan pengganggu pada periode waktu atau ruang dengan kesalahan pengganggu pada waktu atau ruang (sebelumnya).Pengujian menggunakan uji Durbin Watson untuk melihat gejala autokorelasi. Untuk lebih jelas maka dapat dilihat pada tabel 4.11 berikut.

\section{Uji Autokorelasi}

\begin{tabular}{|c|c|c|c|}
\hline R-squared & 0.956639 & $\begin{array}{c}\text { Mean } \\
\text { dependent var }\end{array}$ & 0.410000 \\
\hline $\begin{array}{l}\text { Adjusted } \\
\text { squared }\end{array}$ & 0.898823 & $\begin{array}{l}\text { S.D. } \\
\text { dependent var }\end{array}$ & 0.044401 \\
\hline $\begin{array}{l}\text { S.E.of } \\
\text { regression }\end{array}$ & 0.014123 & $\begin{array}{l}\text { Akaike info } \\
\text { criterion }\end{array}$ & 5.412835 \\
\hline $\begin{array}{l}\text { Sum squared } \\
\text { resid }\end{array}$ & 0.000598 & $\begin{array}{l}\text { Schwarz } \\
\text { criterion }\end{array}$ & 5.363184 \\
\hline $\begin{array}{l}\text { Log } \\
\text { likelihood }\end{array}$ & 26.65134 & $\begin{array}{c}\text { Hannan- } \\
\text { Quinn criter. }\end{array}$ & 5.747711 \\
\hline F-statistic & 16.54647 & $\begin{array}{c}\text { Durbin- } \\
\text { Watson stat }\end{array}$ & 1.952142 \\
\hline $\begin{array}{l}\text { Prob(F- } \\
\text { statistic) }\end{array}$ & 0.021986 & & \\
\hline
\end{tabular}

Sumber: Hasil Olahan Data Sekunder (2019)

Berdasarkan dari hasil pengujian multikolinearitas maka di dapatkan bahwa nilai Centered VIF pada semua variable dependen nilainya kurang dari 10, maka dapat dinyatakan bahwa tidak terdapat masalah multikolinearitas dalam model prediksi.

\section{Pengujian Regresi Linear Berganda}

Analisis regresibergandadigunakanuntuk mengetahui dan menganalisis pengaruh variabel Growth, Unemp, APK dan Aglo terhadap INEQ di Provinsi Aceh tahun 2010-2017. Untuklebih jelas dapat dilihat pada tabel 8 berikut:

\section{Tabel 8}

\section{Regresi Linear Berganda}

Dependent Variable: INEQ

Method: Least Squares

Sample: 20102017

Included observations: 8

\begin{tabular}{lcccl}
\hline \hline Variable & Coefficient & Std. Error & t-Statistic & Prob. \\
\hline \hline C & 1.861131 & 0.340389 & 5.467655 & 0.0120 \\
Growth & 0.001171 & 0.000466 & 2.514665 & 0.0866 \\
Unemp & -0.006746 & 0.004962 & -1.359625 & 0.2671 \\
APK & -0.014930 & 0.003107 & -4.805908 & 0.0172 \\
Aglo & 0.030660 & 0.027919 & 1.098162 & 0.3524 \\
\hline \hline R-squared & 0.956639 & Mean dependent var & 0.410000 \\
Adjusted R-squared & 0.898823 & S.D. dependent var & 0.044401 \\
S.E. of regression & 0.014123 & Akaike info criterion & -5.412835 \\
Sum squared resid & 0.000598 & Schwarz criterion & -5.363184 \\
Log likelihood & 26.65134 & Hannan-Quinn criter. & -5.747711 \\
F-statistic & 16.54647 & Durbin-Watson stat & 1.952142 \\
Prob(F-statistic) & 0.021986 & & & \\
\hline \hline
\end{tabular}

Sumber: HasilOlahan Data Sekunder (2019)

Berdasarkan Tabel 8 diatas dapat disusun persamaan regresi linier berganda sebagai berikut: $I N E Q=1.861131+0.001171$ (Growth) -0.006746 (Unemp) - 0.014930(APK) + 0.030660(Aglo). Dari persamaan di atas dapat diinterpretasikan sebagai berikut:

a. Konstanta $\mathrm{b}_{0}(a)=1,861131$ artinya jika Growth, Unemp, APK dan Aglo nilainya 0, maka INEQ nilainya sebesar $1.861131 \%$.

b. Koefisien $b_{1}=0,001171$ artinya jika variabel Unemp, APK dan Aglo nilainya tetap sedangkan Growth ditingkatkan sebesar 1\% maka INEQ akan meningkat sebesar $0,001171 \%$

c. Koefisien $\mathrm{b}_{2}=-0,006746$ artinya jika variabel Growth, APK dan Aglo nilainya tetap sedangkan Unemp ditingkatkan sebesar 1\% maka INEQ akan terjadi penurunan sebesar $0,006746 \%$.

d. Koefisien $b_{3}=-0.014930$ artinya jika variabel Growth, Unemp, dan Aglo nilainya tetap sedangkan $A P K$ ditingkatkan sebesar $1 \%$ maka INEQ akan terjadi penurunan sebesar $0.014930 \%$

e. Koefisien $b_{1}=0.030660$ artinya jika variabel Growth, Unemp dan APK nilainya tetap sedangkan Aglo ditingkatkan sebesar 1\% maka INEQ akan meningkat sebesar $0.030660 \%$. 


\section{Uji Hipotesis}

\section{Uji Signifikansi Parsial (Uji Statistik t)}

Ujistatistik $\mathrm{t}$ pada dasarnya menunjukan seberapa jauh pengaruh satu variabel independen secara individual dalam menerangkan variasi variabel dependen Berdasarkan Tabel 4.12 dapat diketahui kedua variabel independen berpengaruh signifikan terhadapvariabel dependen

\section{1) Pertumbuhan Ekonomi (Growth)}

Hasil perhitungan secara parsial variabel Growthtidak berpengaruh terhadap variabel INEQ, yang ditunjukkan dengan besarnya nilai probabilitas sebesar 0,0866 dan nilai sig 0,05 $(0,0866>0,05)$.Dari hasil analisis dapat disimpulkan bahwa pertumbuhan ekonomi (Growth)tidak berpengaruh terhadap ketimpangan pendapatan (INEQ). Hasil penelitian ini didukung penelitian yang dilakukan oleh Puti dan Pipit (2017), dalam penelitian tersebut menjelaskan bahwa tidak adanya pengaruh pertumbuhan ekonomi secara parsial terhadap variabel ketimpangan di Provinsi Aceh.

\section{2) Tingkat Pengangguran (Unemp)}

Hasil perhitungan secara parsial variabel Unemp tidak berpengaruh terhadap variabel INEQ, yang ditunjukkan dengan besarnya nilai probabilitas sebesar 0,2671 dan nilai sig 0,05 $(0,2671>0,05)$. Dari hasil analisis dapat disimpulkan bahwa tingkat pengangguran (Unemp) tidak berpengaruh terhadap ketimpangan pendapatan (INEQ). Hasil penelitian ini didukung penelitian yang dilakukan oleh Dea, dkk (2019), dalam penelitian tersebut didapatkan bahwa tingkat pengangguran tidak mempengaruhi ketimpangan distribusi pendapatan daerah.

\section{3) AngkaPartisipasiKasar( $A P K)$}

Hasil perhitungan secara parsial variabel $A P K$ berpengaruh terhadap variabel INEQ, yang ditunjukkan dengan besarnya nilai probabilitas sebesar 0,0172 dan nilai sig 0,05 $(0,0172<0,05)$. Dari hasil analisis dapat disimpulkan bahwa angka partisipasi kasar berpengaruh $(A P K)$ terhadap ketimpangan pendapatan (INEQ). Senada dengan penelitian yang dilakukan oleh Ma'maun (2012) yang menunjukkan bahwa angka partisipasi kasar berpengaruh dengan tingkat ketimpangan.

4)Aglomerasi (Aglo)

Hasil perhitungan secara parsial variabel Aglo tidak berpengaruh terhadap variabel INEQ, yang ditunjukkan dengan besarnya nilai probabilitas sebesar 0,3524dan nilaisig 0,05 $(0,3524>0,05)$. Dari hasil analisis dapat disimpulkan bahwa aglomerasi (Aglo) tidak berpengaruh terhadap ketimpangan pendapatan (INEQ). Namun untuk kajian pengaruh aglomerasi terhadap ketimpangan ekonomi berbeda dari hasil penelitian yang telah dilakukan oleh Mentari (2017) dalam penelitiannya menjelaskan bahwa aglomerasi berpengaruh terhadap ketimpangan ekonomi yang bertentangan dengan hasil penelitian yang peneliti lakukan dimana aglomerasi tidak berpengaruh dengan ketimpangan ekonomi.

\section{Uji Signifikansi Simultan (Uji Statistik F)}

Hasil uji $F$ dengan nilai pada $\operatorname{Prob}(F-$ statistic)sebesar 0,021986 yang dibandingkan dengan nilai signifikansi 0,05 , maka dapat disimpulkan $\mathrm{H}_{0}$ ditolak dan $\mathrm{H}_{\mathrm{a}}$ diterima. Hal ini menunjukkan secara simultan variabel independen yang terdiri dari Growth, Unemp, APK dan Aglo berpengaruh terhadap INEQ artinya besar kecilnya semua variabel independen tersebut secara simultan mempengaruhi perubahan INEQ pada tahun mendatang. Namun untuk keseluruhan variabel penelitian yang dilakukan oleh Puti dan Pipit (2017) bahwa faktor-faktor ekonomi berpengaruh terhadap ketimpangan pendapatan.

\section{Uji Koefisien Determinasi (Uji $\mathbf{R}^{\mathbf{2}}$ )}

Dalam penelitian ini nilai yang digunakan adalah nilai dari Adjusted $R$-squared, Adjusted $R$ squared dalam penelitian ini sebesar 0,898823 yang berarti variabilitas variabel dependen yang dapat dijelaskan oleh variabilitas variabel independen sebesar 89,8\%. Sedangkan sisanya sebesar $10,2 \%$ dapat dijelaskan oleh variabel lain yang tidak termasuk dalam variabel penelitian ini. Dilihat dari nilai Adjusted $R$ Square sebesar 0,898823 maka dapat dinyatakan bahwa besaran 
pengaruh variabel Growth, Unemp, APK dan Aglo terhadap INEQ dinyatakan tinggi.

\section{Pembahasan}

Bedasarkan dari hasil pengujian yang telah dilakukan di atas menunjukkan bahwa pada pengujian indeks Williamson Provinsi Aceh dari tahun 2010-2017 terdapat ketimpangan yang cukup tinggi yaitu sebesar $0,41 \%$ dari keseluruhan tahun yang diujikan. Begitu juga ketimpangan yang dilakukan pengujian dengan indeks Entropi Theil juga mengalami ketimpangan yang sangat tinggi yaitu sebesar $1,47 \%$.

Wilayah dengan tingkat ketimpangan ekonomi dan industri terparah sendiri terjadi di Kota Lhokseumawe dengan indeks Entropi Theil pada tahun 2010 mencapai 4,47\%, walaupun Kota Lhokseumawe merupakan kota dengan PDRB paling tinggi dibandingkan dengan wilayah lain namun pendapatan masyarakatnya tidak merata, walaupun terjadi penurunan ketimpangan ekonomi pada tahun 2017 menjadi sebesar2,26\% tetapi masih dalam ketimpangan yang tinggi, selanjunya Kota Banda Aceh juga mengalami ketimpangan ekonomi yang terparah walaupun Kota Banda Aceh merupakan ibukota ProvinsiAceh dengan tingkat ketimpangan sebesar 3\% sepanjang tahun, disusul Kota Sabang yang juga pengalami ketimpangan ekonomi sepanjang tahun penelitian sebesar $2 \%$.

Sedangkan untuk melihat berpengaruhtidaknya ketimpangan pendapatan dengan pertumbuhan ekonomi,tingkat pengangguran, angka partisipasi kasar dan aglomerasi maka didapatkan bahwa pertumbuhan ekonomi(Growth) tidak berpengaruh terhadap ketimpangan pendapatan(INEQ), tingkat pengangguran(Unemp) tidak berpengaruh terhadap ketimpangan pendapatan (INEQ),angka partisipasi kasar berpengaruh $(A P K)$ terhadap ketimpangan pendapatan(INEQ) dan Aglomerasi(Aglo) tidak berpengaruh terhadap ketimpangan pendapatan (INEQ).

Melihat pernyataan tersebut diatas, penyebab terjadinya ketimpangan pendapatan di Provinsi Aceh dari tahun 2010-2012 disebabkan sumber daya manusia yang ada di Provinsi Aceh yang masih sangat rendah sehingga menyumbang ketimpangan yang terlalu tinggi, sumber daya manusia yang handal mampu menjadi pendorong terjadinya kehidupan yang sejahtera. Dengan demikian diperlukan perhatian pemerintah khususnya Pemerintah Provinsi Aceh serta segenap pemerintah di daerah untuk bersama-sama membentuk sumber daya manusia yang lebih handal.

\section{KESIMPULAN}

Dari hasil penelitian mengenai faktor-faktor yang mempengaruhi ketimpangan pendapatan di Provinsi Aceh maka dapat disimpulkan bahwa.

1. Hasil pengujian ketimpangan dengan menggunakan indeks Williamson di Provinsi Aceh masih cukup tinggi yaitu sebesar $0,41 \%$ dan dari pengujian Indeks Entropi Theil mengalami ketimpangan sangat tinggi yaitu sebesar $1,47 \%$.

2. Pertumbuhan ekonomi(Growth) tidak berpengaruh terhadap ketimpangan pendapatan (INEQ).

3. Tingkat pengangguran (Unemp)tidak berpengaruh terhadapketimpanganpendapatan (INEQ)

4. Angka partisipasi kasar berpengaruh $(A P K)$ terhadap ketimpangan pendapatan (INEQ).

5. Aglomerasi (Aglo)tidak berpengaruh terhadap ketimpangan pendapatan (INEQ).

\section{SARAN}

1. Diharapkan kepada pemerintah Provinsi Aceh setiap kebijakan yang dikeluarkan dapat meningkatkan pendapatan daerah serta mampu menggalih potensi daerahnya untuk menambah pendapatan asli daerah.

2. Pemerintah diharapkan dapat mempertimbangkan kenaikan tingkat upah minimum sesuai dengan tingkat inflasidan tingkat kebutuhan dasar pekerja. Strategi lain yaitu memberi pelatihan keterampilan bagi tenaga kerja yang diharapakan bisa mendorong kemandirian tenaga kerja untuk menciptakan peluang usaha. 


\section{KEPUSTAKAAN}

Adisasmita, Rahardjo. 2011. Pengelolaan Pendapatan dan Anggaran Daerah. Yogyakarta: Graha Ilmu

Amalia, Lia. 2010. Ekonomi Internasional. Yogyakarta: Graha Ilmu

Arikunto, Suharsimi. 2012. ProsedurPenelitian SuatuPendekatanPraktek. Jakarta: Rineka Cipta

Gujarati, D. N. 2013. Dasar-dasar Ekonometrika, Edisi Kelima. Jakarta: Salemba Empat

Iswanto, Denny. 2015. KetimpanganPendapatan AntarKabupaten/Kota DanPertumbuhan Ekonomi DI Propinsi JawaTimur. Jurnal Ekonomi. Yayasan Al-Kahfi Kota Tangerang Selatan

Jhingan, M.L. 2014. Ekonomi Pembangunan dan Perencanaan. Jakarta: Rajawali Pers

Kuncoro, Mudrajad. 2013. Metode Riset untuk Bisnis dan Ekonomi. Edisi 4. Jakarta: Erlangga

Made, Sudana, I. 2011. Manajemen Keuangan Perusahaan Teori dan Praktek. Jakarta: Erlangga

Meliana, dkk 2017. Ketimpangan Wilayah Antar Kabupaten/Kota di Provinsi Lampung. Jurnal Program Studi Perencanaan Wilayah dan Kota, Fakultas Teknik-Universitas Pakuan

Saerofi, Mujib. 2015. Analisis Pertumbuhan Dan Perkembangan Ekonomi Sektor Potensial Semarang. Skripsi. Fakultas Ekonomi Unnes

Sjafrizal. 2011. Ekonomi Regional, Teori dan Aplikasi. Boduose Media. Padang. Sumatera Bara

Sjafrizal. 2012. Pertumbuhan Ekonomidan Ketimpangan Regional Wilayah Indonesia Bagian Barat. Jakarta: Jurnal Buletin Prisma

Sjafrizal. 2014. PerencanaanPembangunan Daerah Dalam Era Otonomi. Jakarta: PT RajagrafindoPersada
Sugiyono. 2015. Metode Penelitian Pendidikan (Pendekatan Kuantitatif, Kualitatif dan $R \& D)$. Bandung: Penerbit CV. Alfabeta

Sukirno, Sadono. 2013. Makroekonomi:Teori Pengantar. Jakarta: PT. Raja Grafindo Persada

Supranto. 2011. Statistik Teori dan Aplikasi. Jakarta: Erlangga

Tarigan, H. G. 2013. Berbicara sebagai suatu keterampilan berbahasa. Bandung: Angkasa

Tipka, Jefri. 2015. Analisis Ketimpangan Pembangunan Antara Kabupaten/Kota Di ProvinsiMaluku. Jurnal Ilmu Matematika dan Terapan

Todaro, Michael P. 2011. Economic Development. Eleventh Edition. United States: Addison Wesley 